\title{
The green turtle Chelonia mydas as a marine and coastal environmental sentinels: anthropogenic activities and diseases
}

\section{Tartaruga-verde, Chelonia mydas, como sentinela do ambiente marinho e costeiro: atividades antrópicas e enfermidades}

\author{
Isabela Guarnier Domiciano후 Camila Domit²; Ana Paula Frederico Rodrigues \\ Loureiro Bracarense ${ }^{3 *}$
}

\begin{abstract}
The green turtle Chelonia mydas is a widely distributed, slowly maturing species with a complex life cycle, using both oceanic and coastal environments. The species is exposed to different threats and is considered an environmental sentinel that indicates variation among, and the severity of hazards to marine ecosystems. This study aimed to describe both anthropogenic impacts, and infectious and parasitic diseases in C. mydas - including cases along the Brazilian coast - and implications for conservation. Bycatch is reported as the main threat to the conservation of this species, followed by debris ingestion, collisions with boats, dredging, and chronic environmental contamination. All of these impacts may directly or indirectly cause death, by facilitating contact with pathological agents and by increasing vulnerability to secondary diseases. The pathological agents associated with lesions include viruses, bacteria, fungi, protozoa, and helminths. Fibropapillomatosis is an example of a chronic disease characterized by cutaneous and visceral tumors that affects mostly juvenile C. mydas worldwide and is associated with the Chelonid herpesvirus 5. The bacterias Vibrio alginolyticus, Aeromonas hydrophila, and Pseudomonas fluorescens are found in the aquatic environment and among C. mydas lesions in various organs. Trematode adults and eggs of the family Spirorchiidae are also frequent in systemic cardiovascular diseases of C. mydas. The direct impacts of anthropogenic activities and diseases are synergistic and may affect the specie's health and conservation. Therefore, the monitoring and systematic diagnosing of diseases and causes of death - including necropsy, histopathology, and molecular exams - are necessary to assess a population's health, to support appropriate decisions of coastal management and to target future research topics that optimize C. mydas conservation.
\end{abstract}

Key words: Bycatch. Conservation. Debris ingestion. Morbidity. Pathogenic agents. Sea turtle.

\section{Resumo}

A tartaruga-verde, Chelonia mydas, possui ampla distribuição geográfica, reprodução tardia e complexo ciclo de vida, habitando áreas costeiras e oceânicas. Devido a essas características, a espécie está exposta a diferentes tipos de ameaças e pode sinalizar sobre variações e a gravidade desses impactos ao longo do tempo no ecossistema, sendo considerada sentinela ambiental. Este trabalho teve por objetivo discorrer sobre relatos de atividades antrópicas impactantes e doenças infecciosas e parasitárias em $C$. mydas, com ênfase nas ocorrências no litoral brasileiro. A captura acidental em petrechos de pesca é uma das principais ameaças à conservação desses animais, assim como a ingestão de resíduos sólidos, colisão com embarcações, dragagens e bioacumulação de contaminantes químicos, os quais podem atuar diretamente ou indiretamente na morte dos animais. Dessa forma, quando não matam o animal, podem servir como porta de entrada para agentes patogênicos e agirem como imunossupressores

\footnotetext{
Discente, Universidade Estadual de Londrina, UEL, Londrina, PR, Brasil. E-mail:isabela.guarnier@hotmail.com

2 Pesquisador, Universidade Federal do Paraná, UFPR, Pontal do Paraná, PR, Brasil. E-mail: cadomit@gmail.com

$3 \operatorname{Prof}^{\mathrm{a}} \mathrm{Dr}^{\mathrm{a}}$, Universidade Estadual de Londrina, UEL, Londrina, PR, Brasil. E-mail: anapaula@uel.br

Author for correspondence
} 
que influenciam no desenvolvimento de doenças secundárias. Os agentes patogênicos associados a lesões incluem vírus, bactérias, fungos, protozoários e helmintos. A fibropapilomatose, por exemplo, é caracterizada por tumores cutâneos e viscerais que afetam C. mydas juvenis no mundo todo, e o provável agente é o Chelonid herpesvirus 5. As bactérias Vibrio alginolyticus, Aeromonas hydrophila, Pseudomonas fluorescens são frequentemente encontradas no ambiente aquático, como também em C. mydas com lesões em diferentes órgãos. Os adultos e ovos de trematódeos da família Spirochiidae também são frequentemente relatados em afecções cardiovasculares sistêmicas em C. mydas. O impacto causado por atividades antrópicas e o desenvolvimento de doenças é sinérgico e afeta a saúde e conservação desses animais. Dessa forma, a avaliação contínua, sistemática, por meio de exames macroscópicos, histopatológicos e auxílio de análises moleculares para identificação de agentes patogênicos é necessária, a fim de avaliar o estado de saúde e subsidiar decisões de gestão costeira, de pesquisa e aprimorar as ações para a conservação de C. mydas.

Palavras-chave: Captura acidental. Conservação. Ingestão de resíduos. Morbidade. Agentes patogênicos. Tartaruga marinha.

\section{Introduction}

Globally, seven species of sea turtles inhabit a diversity of ecological niches in nearly all oceans, including the pelagic leatherback (Dermochelys coriacea) and olive ridley (Lepidochelys olivacea) to neritic green turtles (Chelonia mydas), hawksbill (Eretmochelys imbricata), loggerhead (Caretta caretta), Kemp's ridley (Lepidochelys kempii) and flatback turtles (Natator depressus) (BOWEN; KARL, 2007). The biological (e.g. sexual maturity, body length and morphology) and ecological features (e.g. population size and trends) of each species and different intra-specific populations exhibit geographical variations (WALLACE et al., 2011). Despite this wide range and high variability, all species except $N$. depressus are endangered to some degree, and are listed in the IUCN Red List of Threatened Species due to direct or indirect impacts caused by human activities. These species demonstrate low population recovery, especially because of their long generation time (IUCN, 2017).
Along the Brazilian coast, five species of sea turtles - except L. kempii and N. depressus - are listed as being of concern and facing the same threats as above (ICMBio, 2014). Chelonia mydas (Figure 1) specimens are frequently observed in feeding areas, or found stranded throughout estuarine and coastal areas (SANTOS et al., 2011), and they mainly originate from rookeries off Ascension Island (South Atlantic Ocean) (LUSCHI et al., 1998). The foraging grounds are also used by mixed-genetic stocks, grouping animals from Central America, Trindade Island, and Rocas Atol (PRITCHARD, 1976; LIMA; TROËNG, 2001; NARO-MACIEL et al., 2012, 2014). The distance from Ascension Island to the Brazilian coast is about $2,300 \mathrm{~km}$, but distances as far as $5,000 \mathrm{~km}$ and 5,300 $\mathrm{km}$ have been traveled from Costa Rica and Nicaragua (LUSCHI et al., 1998; LIMA et al., 1999; LIMA; TROËNG, 2001). 
Figure 1. Chelonia mydas stranded at Paraná state, southern Brazil.

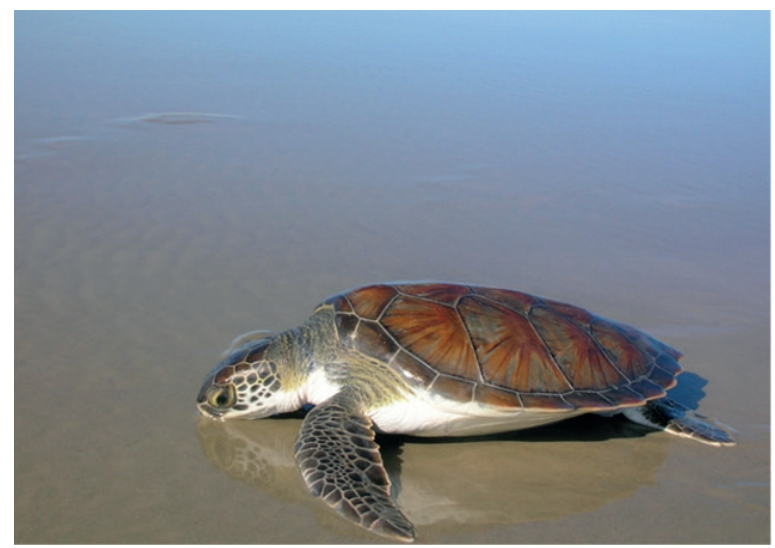

Source: Laboratório de Ecologia e Conservação/UFPR.

The wide migration of C. mydas between oceanic areas during the early years of life, and coastal and estuarine areas in late juvenile stages until adulthood, implies that several potential impacts are faced simultaneously, including (i) seasonal variations and changes in food availability, (ii) physiological changes during their ontogenetic development (e.g. gradual shift from an omnivorous to herbivorous diet) and (iii) different impacts caused by human activities and contact with pathogens (FLINT, 2013; SANTOS et al., 2015). Therefore, C. mydas is considered an environmental sentinel that can indicate hazards and which ultimately can be used to support priority actions to address intervention to maintain or improve the environmental quality and animal's health across regional and global scales (AGUIRRE; LUTZ, 2004; REIF, 2011).

Considering the above, our aim was to review the hazards and health problems of C. mydas associated with human activities, and infectious or parasitic diseases, with special attention to cases reported along the Brazilian coast.

\section{Mortality and morbidity of Chelonia mydas associated with human impacts}

Human activities directly or indirectly affect the morbidity and mortality of C. mydas. Such impacts include: bycatch by active or abandoned, lost or otherwise discarded fishing gears; boat collisions; environmental contamination and dissemination of pathological agents from domestic, agricultural and industrial run-offs; debris ingestion; and habitat loss, with consequent alterations of nesting and feeding areas (HARVELL et al., 1999; FLINT, 2013; SCHUYLER et al., 2014a, 2014b; GAMA et al., 2016).

Bycatch (i.e. incidental capture by marine fisheries targeting other species) is recognized as one of the main contributors towards the decline of sea turtles worldwide, including C. mydas, and affects animals in all developmental stages across feeding, migratory and reproductive areas (WALLACE et al., 2011; LEWISON et al., 2013). The estimates of population sizes, fishing effort and bycatch rates in different areas indicate that more animals are being removed than recovery rates can support (WALLACE et al., 2013; CASALE; HEPPELL, 2016). The impacts of bycatch might be even worse than available estimations, because this varies in space and time, and individual populations can interact with multiple fishers across their range (WALLACE et al., 2013).

Bycatch can cause death directly or indirectly, by causing trauma and secondary cutaneous 
infection, impaired swimming and feeding when fishing nets/lines or hooks attach to the body or within the digestive tract (Figure 2A); or cause intussusception and intestine rupture with secondary bacterial infection (ORÓS et al., 2005; WORK et al., 2015a; NELMS et al., 2016). However, the effects of these indirect impacts are rarely evaluated since they include uncertainties that inhibit robust diagnoses. The pathological findings of confirmed bycaught $C$. mydas have demonstrated lung edema (Figure 2B), atelectasis and emphysema, linear net marks on the skin (Figure 2C), muscular necrosis, and hemorrhage in the celomatic cavity (WORK; BALAZS, 2010; PHILLIPIS et al., 2015). A detailed internal examination is necessary during the diagnosis of suspected cases of drowning, because external findings, such as net marks, are not always apparent (WORK et al., 2015a).
Another consequence of fishing is decompression sickness (barotrauma), which has been observed in bycaught loggerhead turtles $(C$. caretta) which were rapidly dragged to the surface from depths of between 10 to $75 \mathrm{~m}$. The living animals were comatose, hyperactive or developed progressive neurological symptoms, and some specimens were recovered dead (GARCÍA-PÁRRAGA et al., 2014). The ultrasound and post mortem examination revealed intravascular gas bubbles in the lungs, liver, kidney, spleen, mesentery, heart - with greater prevalence in the right atrium than the left, major vessels, and perivascular edema and hemorrhage in different tissues (GARCÍA-PÁRRAGA et al., 2014). Although information describing decompression sickness in C. mydas is scarce, two fresh C. mydas carcasses found stranded in the state of Paraná, southern Brazil, demonstrated copious bubbles in the heart and major vessels (Figure 2D).

Figure 2. Gross findings in Chelonia mydas associated with fishing activities. A. Nylon intake. B. Lung edema. C. Linear trauma and caseous exudate in axillar region, indicating fishing net contact. D. Small and severe presence of bubbles in right atrium (RA) and out of the great vessels (arrow, inset; LA: left atrium and V: ventricle), indicating embolism.
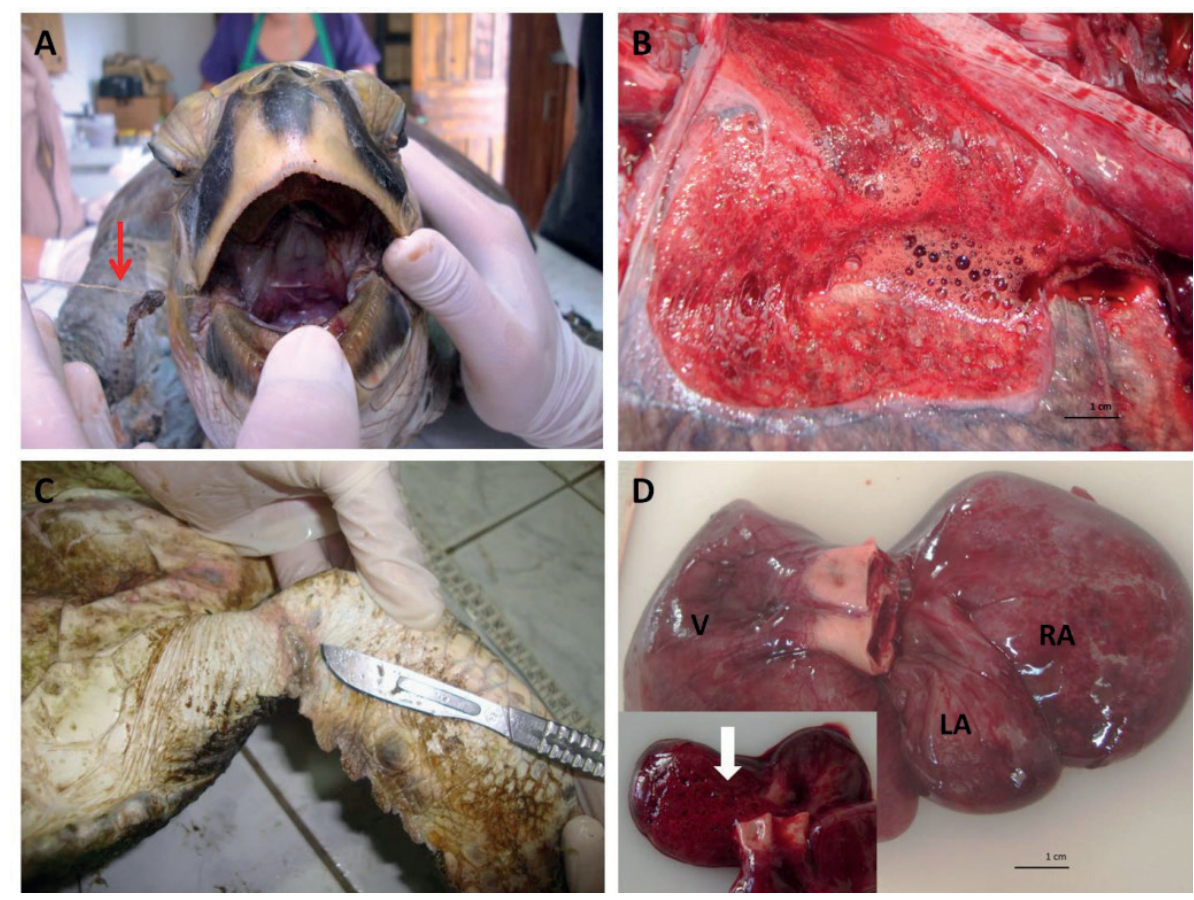

Source: Laboratório de Ecologia e Conservação/UFPR. 
Along the Brazilian coast, bycatch is also the main threat to $C$. mydas conservation, and affects animals in both coastal and oceanic areas (GALLO et al., 2006; PUPO et al., 2006; SALES et al., 2008; SANTOS et al., 2011; FIEDLER et al., 2012; LÓPEZ-BARRERA et al., 2012; MONTEIRO et al., 2016). The high density of small-scale fisheries overlaps coastal areas used by juvenile C. mydas. Ethnobiological analyses in the state of Santa Catarina and Paraná, southern Brazil, indicate that geographic area, depth and the mesh size of nets are associated with increased bycatches in feeding areas (PUPO et al., 2006; LÓPEZ-BARRERA et al., 2012).

Another anthropogenic impact is vessel collision which may cause trauma, crushed tissues and hemorrhaging, usually at the carapace, plastron and head, and even flipper amputation (ORÓS et al., 2005). Such impacts can lead to death or disorientation, debility, and may cause secondary infectious diseases, especially in the lungs and kidneys, located next to carapace and spine. Injuries caused by boat collision are visually similar to lesions caused by dredging activities (GOLDBERG et al., 2015). Dredging is the excavation and removal of sediment from the seafloor, e.g. around ports, to deepen and widen navigation fairways (TORRES et al., 2009). During active dredging operations, the hopper dredge dragheads are slow-moving (and nearly silent while suctioning sediments), and can potentially cause sea turtle injuries or death, as observed in C. mydas stranded dead next to dredging areas off Rio de Janeiro, southern Brazil (GOLDBERG et al., 2015).

Another associated impact is marine pollution, which is linked to the harbor, agriculture, industrial and domestic wastewaters with persistent organic compounds such as polychlorinated biphenyls PCBs, dichlorodiphenyltrichloroethane - DDTs, and trace elements like arsenic, lead and zinc (ISLAM; TANAKA, 2004). These compounds are present in water bodies or attached to sediments and may resuspend during erosion, rain loading, upwellings or dredging activities (ISLAM; TANAKA, 2004; TORRES et al., 2009). Environmental xenobiotics may bioaccumulate and be biomagnified in $C$. mydas according to their diet, age, body length, geographical area and also the tissue that is analyzed (GAUS et al., 2012; KELLER, 2013). Age, body length, diet and chemical pollutant levels have been associated with ontogenetic shifts in C. mydas, from greater levels in hatchlings to early juveniles that have an omnivorous diet, than late juveniles and adults that have a primarily herbivorous diet, and consequently a lower contaminant intake (LABRADA-MARTAGÓN et al., 2011; SILVA et al., 2016). Additionally, chemical levels may vary according to the geographical area, natural enrichment of trace elements and feeding preferences, and also as a result of overlapping anthropogenic activities and residence patterns of C. mydas (LABRADA-MARTAGÓN et al., 2011; BEZERRA et al., 2015).

One example of the above impacts involves $C$. mydas juveniles sampled in two feeding areas in the state of Ceará and the state of Bahia, in northeastern Brazil. These individuals demonstrated mean trace element levels of mercury, aluminum, cadmium and lead similar to highly impacted areas such as China, Australia and Japan, and are among the highest along the Brazilian coast (BEZERRA et al., 2015; MACÊDO et al., 2015). One of those areas in Bahia is considered an industrialized and populated area with consequently a raised level of environmental contamination, but the studied area in Ceará is considered pristine with a low mercury baseline (BEZERRA et al., 2015).

The knowledge of contaminant levels and associated risks of adverse effects are still scarce for sea turtles (GAUS et al., 2012). Trace elements and organic contaminants are relatively low in $C$. mydas tissues and blood samples compared to other vertebrates (GAUS et al., 2012). Nevertheless, trace elements like lead, copper, and iron have been associated with altered blood patterns and oxidative stress parameters that possibly affect 
the dynamics of tumor pathogeny (SILVA et al., 2016). Conversely, no consistent pattern of organic contaminant levels was observed to explain the difference between healthy and tumor-affected $C$. mydas in Brazil (SANCHEZ-SARMIENTO et al., 2017). The knowledge of those concentrations is still needed to obtain a better understanding of the cause-and-effect relationships of environmental contamination and $C$. mydas health parameters (KOMOROSKE et al., 2011).

Controversially, the consumption of turtle products (meat, eggs, organs and blood) by humans has been raising concerns for public health, including organic and inorganic toxic contamination and potential zoonotic diseases (WARWICK et al., 2013). Although consumption is widely illegal, including in Brazil, there have been several poisoning outbreaks caused by sea turtle meat and egg ingestion, mainly observed in the Indo-Pacific region, especially Madagascar, Malay Archipelago, Sri Lanka, Cambodia, southerm India and French Polynisia (FUSSY et al., 2007; SANTOS et al., 2011). The turtle-endemic biotoxin, chelonitoxin, has not been identified, but investigations suggest that it is derived from certain species of invertebrates or algae in the diet of sea turtles and can cause nausea, vomiting, pain, polyarthralgia, drowsiness or psychomotor agitation, multiorgan failure, coma and ultimately death in humans (FUSSY et al., 2007; HADDAD JÚNIOR, 2016). Furthermore, levels of trace elements and organic compounds in sea turtle tissue have exceeded international food safety standards with possible toxic effects, including neurotoxicity, cancer, and developmental effects, especially in fetuses and children (AGUIRRE et al., 2006).

Marine debris, such as flexible and hard plastics, fishing lines, rope, and Styrofoam are another type of marine pollution and can cause death or sub-lethal effects to sea turtles worldwide, particularly $C$. mydas (SCHUYLER et al., 2014a). Debris ingestion may occur passively when it is mixed with normal dietary items or actively when it visually resembles prey items, in addition to the conceivable smell and taste due to the microbial biofilm formation on plastic items (NELMS et al., 2016). Sea turtles are visually selective in what they eat but highly flexible and translucent items, like plastic bags, are easily misidentified and consumed (SCHUYLER et al., 2014b).

Ingested debris has been shown to remain inside in the digestive tract of captive $C$. mydas from between at least few days to four months (LUTZ, 1990) and possible consequences are reduction of absorption efficiency, absorption of plasticizers (such as bisphenol A and phthalates, considered potential endocrine disrupters), perforation and obstruction of the gastrointestinal tract, inanition that may lead to reduced growth and reproduction rates, vulnerability to predation and death (BJORNDAL, 1997; SCHUYLER et al., 2014a; NELMS et al., 2016). Marine debris also includes abandoned, lost or otherwise discarded, fishing gears that entangle sea turtles and cause abrasions, flipper amputation or a reduced ability to forage due to drag. All of these impacts may lead to starvation or drowning (NELMS et al., 2016).

Although the source of debris ingested by $C$. mydas can be geographically different from the stranding area, the frequency of marine debris seems to vary per sampled region and life stage (SCHUYLER et al., 2014b). The frequency of juveniles stranded with ingested debris in Uruguay (South America) has been estimated at $73 \%$, but reached $90 \%$ in Rio de la Plata - for both margins (Uruguay and Argentina/GONZÁLEZ-CARMAN et al., 2014; TERYDA, 2015). Similarly, high frequencies of debris ingestion were observed along the Brazilian coast, and varied from $\sim 60 \%$ to $100 \%$ in Rio Grande do Sul, southern Brazil (BUGONI et al., 2001; TOURINHO et al., 2010), 70\% in Paraná state, southern Brazil (GUEBERT-BARTHOLO et al., 2011; GAMA et al., 2016), from 45\% to 70\% in São Paulo state, southeastern Brazil (BEZERRA, 2014; MENDES et al., 2015), 60\% from Rio de Janeiro to Espírito Santo state, southeastern Brazil 
(DiBENEDITTO; AWABDI, 2014; SANTOS et al., $2015)$ and $70 \%$ in Sergipe state, northeastern Brazil (SANTOS et al., 2015). It is interesting to note that the large frequencies of debris ingestion observed in Uruguay, Argentina and Brazil are a warning for the conservation of $C$. mydas, because these areas are considered to be part of an important migratory corridor in the southwestern Atlantic Ocean.

The type and severity of lesions associated with debris ingestion are poorly documented. In some areas cited above, death rates can vary from 0 to $29 \%$. Only $0.5 \mathrm{~g}$ of debris is enough to obstruct the intestine and lead to starvation and ultimately, death (BUGONI et al., 2001; TOURINHO et al., 2010; SANTOS et al., 2015). Other negative impacts of marine pollution are obstacles that create difficulties for (i) females to select an ideal site to nest and (ii) hatchlings to travel from the nest towards the sea, with consequently a greater vulnerability to predation and grounding at nesting beaches, and (iii) eggs permeability and/or temperature alteration, which can influence dehydration and sex ratio, since sea turtles are sex temperature-dependent (NELMS et al., 2016).

Mortality and morbidity of Chelonia mydas associated with infectious and parasitic diseases

The infectious and parasitic diseases in captive and free-ranging sea turtles include a great variety of pathogenic agents, particularly zoonotic and often opportunistic pathogens, which are found in their diet and environment (LAUCKNER, 1985; GLAZEBROOK; CAMPBELL, 1990a; ORÓS et al., 2005; FLINT et al., 2010; WORK et al., 2015a). Evaluating the severity of a disease and the causal relationship with the death of an organism is complex since infectious and parasitic agents are inherently present in wild animals (WOBESER, 2007). For this topic, we therefore only considered information about pathogens related to diseases and/or secondary findings in C. mydas.
Fibropapillomatosis (FP) is a chronic disease characterized by multiple cutaneous or visceral tumors in sea turtles, mainly juvenile C. mydas, in tropical coastal areas worldwide (AGUIRRE; LUTZ, 2004; GREENBLATT et al., 2005). The neoplasia is benign, but according to size, number and distribution, the tumors may impair vision, diving, and feeding, due to growth on eyelids, axillar and inguinal areas, flippers and mouth (HERBST, 1994) (Figure 3A). In Brazil, the prevalence of cutaneous tumors varies greatly from an absence on individuals at nesting islands far from the coastline to $61.7 \%$ among those at the coast of southeastern Brazil (DOMICIANO, 2016).

The visceral tumors are observed in the lungs, kidneys, heart, skeletal muscles, gastrointestinal tract, and spleen, with a diameter of 0.1 to $20.0 \mathrm{~cm}$ and are classified as fibromas, myxofibromas or fibrosarcomas of low-grade malignancy (HERBST, 1994; WORK et al., 2004). Internal tumors may impair the functions of organs and increase the vulnerability of turtles to secondary infections and dehydration, leading to debilitated health or death (WORK et al., 2004; FLINT et al., 2009). The cases of visceral tumors in C. mydas along the Brazilian coast include fibromas in the kidneys, lungs, and heart (BAPTISTOTTE, 2007; DUTRA et al., 2012), but the frequency of these tumors might be lower in Brazil than other areas, such as Hawaii, where internal tumors have been observed in 39\% of necropsied animals (WORK et al., 2004; BAPTISTOTTE, 2007; DUTRA et al., 2012).

Although FP occurs globally, the etiological agent and the transmission remain undetermined, but the Chelonid herpesvirus 5 (ChHV5) DNA is often detected in tumors from different sea turtle species and regions, and is the most commonly accepted agent (DOMICIANO et al., 2013; WORK et al., 2015b; JONES et al., 2016). Recently, ChHV5 DNA was also detected in saliva and ocular secretion of FP-affected C. mydas in southeastern Brazil, and added to skin contact, it represents another possible 
pathway for virus shedding (MONEZI et al., 2016). Fibropapillomatosis is associated with the life cycle of $C$. mydas, because tumors are observed in postrecruitment juveniles and adults in neritic areas but is absent in oceanic areas (ENE et al., 2005; JONES et al., 2016). Some environmental factors, such as high levels of contamination, water temperature and concentration of viral strains in neritic areas have been associated with FP (HERBST, 1994; SANTOS et al., 2010; RODENBUSCH et al., 2014).

Figure 3. Infectious and parasitic diseases in Chelonia mydas. A. Fibropapillomatosis characterized by cutaneous tumors in axillar and inguinal areas (arrows). B. Granulomatous pneumonia with intralesional hyphae (arrow; Grocott stain) C. Parasitic granulomas, rounded and whitish areas in intestinal serosa. D. Granulomatous nephritis with multifocal yellowish areas of necrosis (kidneys limited by dashed line).
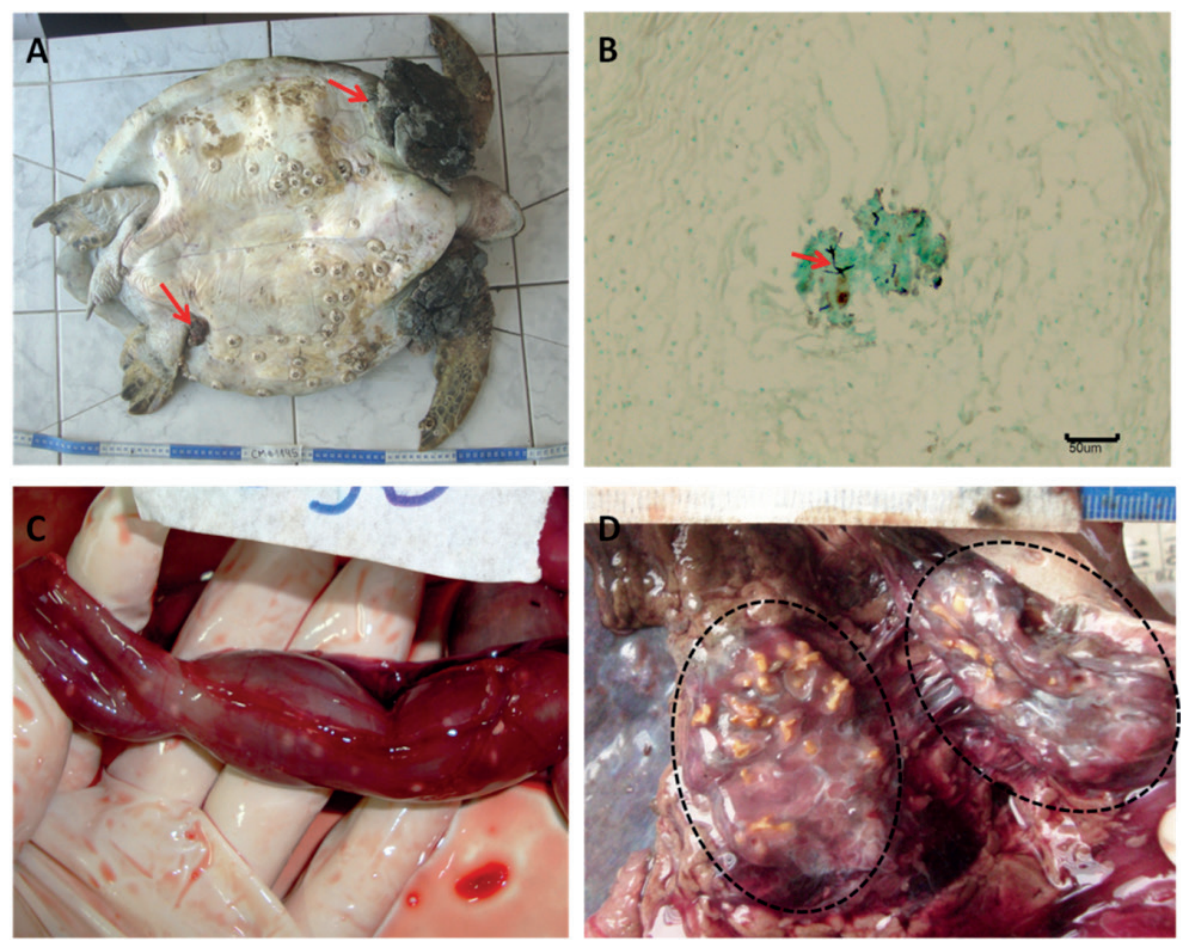

Source: Laboratório de Ecologia e Conservação/UFPR.

Other observed skin diseases in C. mydas include whitish and small lesions that microscopically presented epidermis hyperplasia with severe parakeratotic hyperkeratosis and intranuclear inclusion bodies identified as Chelonia mydas papillomavirus (CmPV) (MANIRE et al., 2008). After several months, the lesions were slough, leaving a dark, slightly raised periphery with a slightly sunken center which eventually disapeared completely (MANIRE et al., 2008). These lesions were similar to other reptile lesions and resembled very early papillomavirus lesions in mammals, but typically lobulated, pedunculated growths were not observed (MANIRE et al., 2008). Papular dermatitis - also known as gray-patch disease - associated with herpesvirus and lacerative dermatitis associated with secondary bacterial infections were observed in captive animals (GEORGE, 1997; GLAZEBROOK; CAMPBELL, 1990a). The benign form of graypatch disease included numerous nonspreading 
papules or pustules, but other cases demonstrated rapidly spreading gray lesions with raised edges, which represent areas of superficial maceration that sometimes envolved the entire turtle and for juveniles could cause death (GEORGE, 1997). Ulcerative dermatitis and fibrosis were also associated with parasite leeches and the contact of barnacles or a consequence of trauma (due to biting) in both free-ranging and captive animals (LAUCKNER, 1985; SANTORO et al., 2007; FLINT et al., 2009). The severity of lesions may vary according to distribution and ectoparasite load, but severely affected animals demonstrated anemia and extensive dermatitis which could facilitate secondary bacterial and fungi infections (GEORGE, 1997; FLINT et al., 2009).

Any respiratory lesions of $C$. mydas are usually detected clinically when the animal presents nasal discharge, inappetence, lethargy, lung crackling and impaired balance control (LAUCKNER, 1985; ORÓS et al., 2005). The obstructive rhinitis-ulcerative stomatitis-bronchopneumonia has been a main disease involving upper and lower respiratory tract in captive C. mydas, with bacterial infection including Vibrio alginolyticus, Aeromonas hydrophila, Pseudomonas fluorescens and Cytophaga-Flavobacterium. Granulomatous pneumonia associated with Mycobacterium spp. and fungi (Figure 3B) like Paecilomyces spp. have also been detected in captive animals (BROCK et al., 1976; GLAZEBROOK; CAMPBELL, 1990a). Other diseases in captive $C$. mydas include necrotic tracheitis and severe pneumonia associated with herpesvirus infection (JACOBSON et al., 1986). Granulomatous tracheitis was observed in freeranging C. mydas associated with fungi Veronaea botryosa, Cladosporium spp., Ochroconis spp. and Cochliobolus spp. (DONNELLY et al., 2015), and similar to captive animals, pneumonia associated with a Mycobacterium spp. infections were observed in free-ranging animals (FLINT et al., 2010).

In Brazil, a severe granulomatous pneumonia associated with Spirorchiid trematode probably caused the death of a C. mydas stranded in Santa Catarina state (GOLDBERG et al., 2013). In other cases, parasitic pneumonia and splenitis caused by trematode eggs were frequently observed in stranded C. mydas in Espírito Santo state, but were not linked with any animal's death (BINOTI et al., 2016), suggesting that different levels of susceptibility vary according to parasitic burdens and the intensity of infection.

Lesions of the cardiovascular system in C. mydas are frequently associated with trematode flukes and eggs of the family Spirorchiidae (STACY et al., 2010). The parasites can attach to the inner surface, or remain free within the cardiac chambers and vessels and are disseminated in the circulation to various organs like spleen, thyroid, gastrointestinal tract, lung, kidney and brain (GORDON et al., 1998; WORK et al., 2005; SANTORO et al., 2007; STACY et al., 2010). Associated gross and histological lesions can include mural necrotizing endocarditis, arteritis, thrombosis - frequently accompanied by aneurism formation, infarcts, granulomatous infection and hemorrhage (GORDON et al., 1998; SANTORO et al., 2007; FLINT et al., 2009). The eggs are classified as: type 1 - elongate and present two processes, one of which is frequently hooked - resembling eggs of the genus Learedius, Monticellius and Hapalotrema; type 2 - ovoid with a sharp short terminal process - resembling eggs of the genera Carettacola and Haemoxenicon; and type 3 - smaller and rounder than other types and lack a process - resembling eggs of the genera Neospirorchis (WOLKE et al., 1982).

Observations of good physical condition and mild necropsy findings in C. mydas infected with spirorchiidiasis rescued offFlorida/USA, Costa Rica and Taiwan indicate that spirorchiidiasis represented secondary lesions and not the main cause of death (SANTORO et al., 2007; STACY et al., 2010; CHEN et al., 2012). Conversely, C. mydas rescued in Hawaii and Australia demonstrated poor body condition, severe lesions and high parasitic burdens that may have led to their death (GORDON et al., 
1998; WORK et al., 2005). Both the cause of death and secondary lesions have been associated with Spirorchiidae parasitosis in Brazil (GOLDBERG et al., 2013; WERNECK et al., 2015a; BINOTI et al., 2016). Therefore, continuous monitoring covering different geographic regions and identification of parasitic species may contribute towards a better understanding of associated pathologies or death and variation according to $C$. mydas age and nutritional status (GORDON et al., 1998; STACY et al., 2010). Cardiac fibromas were also observed in a C. mydas stranded in southeastern Brazil (DUTRA et al., 2012).

Gastrointestinal lesions observed in C. mydas include esophagitis associated with the trematode Rameshwarotrema uterocrescens (Digenea: Pronocephalidae) (SANTORO et al., 2007), and caseous stomatitis and fibronecrotic esophagitis due to hook ingestion and perforation associated with secondary infection by Vibrio alginolyticus, Aeromonas hydrophila, Pseudomonas spp., Escherichia coli and Staphylococcus spp. (ORÓS et al., 2004). Caseous esophagitis was also associated with bacteria gram positive and trematode infection (Pronocephalidae, Microscaphididae, Cladorchiidae and Rhytidodidae) in C. mydas from southeastern Brazil. In these cases, $24.3 \%$ of $C$. mydas presented total esophageal obstruction (CALAIS JÚNIOR, 2015).

Noted gastric lesions for C. mydas include petechia, mucosal hyperplasia, and necrosis associated with trematodes Charaxicephaloides spp. and Charaxicephalus robustus (Digenea: Pronocephalidae) (SANTORO et al., 2007). The nematode Sulcascaris sulcata is occasionally observed in C. mydas, including a case in Brazil (FREITAS; LENT, 1946), which was infected while feeding in areas with mollusks, which are possibly intermediate hosts (LICHTENFELS et al., 1978). Sulcascaris sulcata can cause ulcers, fibrinopurulent gastritis and chronic gastritis (LAUCKNER, 1985). Nematodes of the family Anisakidae - Anisakis simplex and A. typica - were also observed associated with hemorrhagic ulcers, gastritis and cystis in serosa in captive (BURKE; RODGERS, 1982; GLAZEBROOK; CAMPBELL, 1990a) and in a free-ranging C. mydas in Brazil (XAVIER, 2011). The transmission possibly occurred by the ingestion of infected fish, and because the Anisakis spp. migrates through the celomic cavity, they may cause tissue fibrosis and granulomas (GLAZEBROOK; CAMPBELL, 1990a).

The intestinal diseases in C. mydas include intussusception, rupture and lumen obstruction, catarrhal enteritis, fibrinous and necrotizing enteritis, abscesses and granulomas, fibrinous serositis associated with bacterias such as Bacillus spp., Escherichia coli, Pasteurella spp., Proteus spp., Serratia marcescens, Staphylococcus spp., Streptococcus spp. and Vibrio alginolyticus (ORÓS et al., 2005; FLINT et al., 2009; WORK et al., 2015a). Parasites are frequently observed in C. mydas intestines, although few studies have conducted systematic evaluations of lesions associated with parasite presence, like severe exudative enteritis associated with the protozoa Charyospora cheloniae outbreaks in captive and free-ranging animals (GORDON et al., 1993; FLINT et al., 2009; CHAPMAN et al., 2016) or thickness of intestine wall with whitish or black areas (Figure 3C) with edema, enteritis and granulomatous vasculitis associated with Spirorchiidae trematode and bacteria and fibrinous-hemorrhagic serositis associated with bacilli gram negative (RAIDAL et al., 1998; SANTORO et al., 2007; FLINT et al., 2010; WORK et al., 2015a).

The hepatic lesions in sea turtles are usually nutritional - lipidosis - observed in cachectic animals or a consequence of metabolic and endocrine dysfunctions (FLINT et al., 2009). Infectious hepatitis in $C$. mydas includes granulomatous infiltrate and necrosis associated with Spirorchiidiasis, fungi or bacterial infections (RAIDAL et al., 1998; FLINT et al., 2009; STACY et al., 2010; WERNECK et al., 2015b; WORK et al., 2015a). It is interesting to note the distribution 
and intensity of melano-macrophages in the liver. These leucocytes are usually found in the liver of reptiles, amphibians and fish, but may vary according to phagocytosis effort of old red blood cells, as infectious and parasitic agents (JOHNSON et al., 1999). An in vitro study demonstrated that the melano-macrophages of sea turtles have greater phagocytic activity against the target $E$. coli at low temperatures $\left(2-7^{\circ} \mathrm{C}\right)$ in comparison with mammal macrophage, increasing the immune defense of pecilothermic sea turtles (JOHNSON et al., 1999). The hyperplasia and hypertrophy evaluation of melano-macrophages may reflect the severity of unspecific lesions as chronic infection and stress (FLINT et al., 2009).

The gallbladder lesions include hyperplasia and mucosa thickness, lymphocytic infiltrate, capillary and lymphatic vessels dilation associated with the trematode Rhytidodoides similis (SMITH et al., 1941; SANTORO et al., 2007). Bile usually has a dark green color, but it may change to a crystalline or thick appearance in the presence of parasites (FLINT et al., 2009). Mild granulomatous hepatitis and trematode $R$. similis were observed in the gallbladder of a C. mydas in Espírito Santo state, in southeastern Brazil (WERNECK et al., 2015b).

Lesions in the genitourinary system include renal fibroma in FP-afflicted animals, degeneration and tubular necrosis, granulomatous nephritis (Figure 3D) and chronic interstitial nephritis associated with the protozoa C. cheloniae and trematode eggs (LAUCKNER, 1985; WORK et al., 2004; STACY et al., 2008; FLINT et al., 2010). Degeneration, necrosis and granulomatous nephritis caused by calcium oxalate crystals were also observed (STACY et al., 2008). Other findings include edema and mucosal hyperplasia, serositis and granulomatous cystitis and oophoritis associated with trematodes (LAUCKNER, 1985; FLINT et al., 2009, 2010).

Lesions obsereved in the central nervous system include granulomatous meningoencephalitis and abscess associated with gram negative bacteria, Corynebacterium spp., adults and eggs of trematodes and the protozoa $C$. cheloniae (GEORGE, 1997; RAIDAL et al., 1998; FLINT et al., 2009). Enophtalmia associated with dehydration, keratoconjunctivitis and blepharitis associated with post-trauma bacterial infection were observed in the eyeball of captive C. mydas. Other findings include fibrinous keratitis, fibropapillomas and leech parasitism in eyelids (FLINT et al., 2009).

Cutaneous and mucosal traumas and water inhalation of sea turtles provide opportunities for bacteria and fungi to enter, and may lead to systemic infections or septicemia (GEORGE, 1997; WORK et al., 2003). Gram negative bacteria observed in abscesses of multiple organs have been associated with septicemia in C. mydas (WORK et al., 2015a). Bacteremia has also been associated with Citrobacter freundii, Burkholderia capacia, Shewanella putrefasciens, Staphylococcus sciuri, Salmonella spp., Moraxella spp., Bacillus spp., Escherichia coli, Aeromonas spp., Pseudomonas spp. and Vibrio spp in both living and dead, and captive and freeranging C. mydas (GLAZEBROOK; CAMPBELL, 1990a, 1990b; RAIDAL et al., 1998; WORK et al., 2003).

Disseminated infections can also occur as secondary diseases, observed in cases of FP and moderate-to-severe parasitosis (RAIDAL et al., 1998; WORK et al., 2003). The ulcers in fibropapillomas and vascular lesions caused during parasite egg migration are possible dissemination routes of bacteria into the bloodstream which, in addition to the primary disease, can undermine the immune system of sea turtles (RAIDAL et al., 1998; WORK et al., 2003).

\section{Conclusions}

Scientific studies about parasitic and infectious diseases and human threats to sea turtle conservation have been increasing in the last few decades. This effort is possibly a result of improved diagnosis 
technology, a greater level of anthropogenic impacts on marine ecosystems, and a management and scientific coalition to increase the conservation effort. In Brazil, there are few studies monitoring diseases such as FP and parasitosis, especially studies investigating causes of death in C. mydas are scarse. Additionally, there are hardly any studies investigating how human activities are affecting individuals and their populations. The impacts that affect $C$. mydas and its habitat are synergistic, and the medium-to-long term consequences for the conservation of this species are still not measurable. This uncertainty combined with high mortalities has caused this species to be rated as 'Vulnerable' by the IUCN. Given the current scenario, sea turtle monitoring and health assessments, such as the systematic investigations of diseases and causes of death, should be continuous, including macroscopic, histopathological, chemical and molecular exams to identify pathogens and destructive health effects. This information will provide a knowledge base to support appropriate coastal management decisions, and to target future research topics in order to optimize C. mydas conservation.

\section{Acknowledgments}

We would like to thank the research team from LEC/UFPR and Tara Van Belleghem for their help in editing this document. Isabela G. Domiciano received a CAPES grant (Process 99999.005563/2014-03). Ana Paula F. R. L. Bracarense received a CNPq grant (302816/2014-3).

\section{References}

AGUIRRE, A. A.; GARDNER, S. C.; MARSH, J. C.; DELGADO, S. G.; LIMPUS, C. J.; NICHOLS, W. J. Hazards associated with the consumption of sea turtle meat and eggs: a review for health care workers and the general public. EcoHealth, New York, v. 3, n. 3, p. 141153, 2006.

AGUIRRE, A. A.; LUTZ, P. L. Marine turtles as sentinels of ecosystem health: is fibropapillomatosis an indicator? EcoHealth, New York, v. 1, n. 3, p. 275-283, 2004.
BAPTISTOTTE, C. Caracterização espacial e temporal da fibropapilomatose em tartarugas marinhas da costa brasileira. 2007. Tese (Doutorado em Ecologia) Universidade de São Paulo, Piracicaba.

BEZERRA, D. P. Ingestão de resíduos sólidos por tartarugas-verdes (Chelonia mydas) em áreas de alimentação dentro de um mosaico de unidades de conservação no sul do estado de São Paulo, Brasil. 2014. Dissertação (Mestrado em Ciências Biológicas) Universidade Federal do Paraná, Curitiba.

BEZERRA, M. F.; LACERDA, L. D.; REZENDE, C. E.; FRANCO, M. A. L.; ALMEIDA, M. G.; MACEDO, G. R.; PIRES, T. T.; ROSTAN, G.; LOPEZ, G. G. Food preferences and $\mathrm{Hg}$ distribution in Chelonia mydas assessed by stable isotopes. Environmental Pollution, London, v. 206, n. 1, p. 236-246, 2015.

BINOTI, K.; GOMES, M. C.; CALAIS JÚNIOR, A.; WERNECK, M. R.; MARTINS, I. V. F.; BOELONI, J. N. Helminth fauna of Chelonia mydas (Linnaeus, 1758) in the south of Espírito Santo state in Brazil. Helminthologia, Bratislava, v. 53, n. 2, p. 195-199, 2016.

BJORNDAL, K. A. Foraging ecology and nutrition of sea turtles. In: LUTZ, P. L.; MUSICK, J. (Ed.). The biology of sea turtles. Boca Raton: CRC Press, 1997. v. 1, p. 397-409.

BOWEN, B. W.; KARL, S. A. Population genetics and phylogeography of sea turtles. Molecular Ecology, Oxford, v. 16, n. 23, p. 4886-4907, 2007.

BROCK, J. A.; NAKAMURA, R. M.; MIYAHARA, A. Y. Tuberculosis in Pacific green sea turtle, Chelonia mydas. Transactions of the American Fisheries Society, Bathesda, v. 105, n. 4, p. 564-566, 1976.

BUGONI, L.; KRAUSE, L.; PETRY, M. V. Marine debris and human impacts on sea turtles in southern Brazil. Marine Pollution Bulletin, Oxford, v. 42, n. 12, p. 1330-1334, 2001.

BURKE, J. B.; RODGERS, L. J. Gastric ulceration associated with larval nematodes (Anisakis sp. type 1) in pen reared green turtles (Chelonia mydas) from Torres strait. Journal of Wildlife Diseases, Ames, v. 18, n. 1, p. 41-46, 1982.

CALAIS JÚNIOR, A. Caracterização histomorfológicae histoquímica de esôfagos de tartarugas-verdes (Chelonia mydas) com e sem alterações no litoral do Espírito Santo. 2015. Dissertação (Mestrado em Medicina Veterinária) Universidade Federal do Espírito Santo, Alegre.

CASALE, P.; HEPPELL, S. S. How much sea turtle bycatch is too much? A stationary age distribution model for simulating population abundance and potential biological removal in the Mediterranean. Endangered 
Species Research, Oldendorf, v. 29, n. 3, p. 239-254, 2016.

CHAPMAN, P. A.; OWEN, H.; FLINT, M.; TRAUB, R. J.; CRIBB, T. H.; MILLS, P. C. Molecular characterization of coccidia associated with an epizootic in green turtles (Chelonia mydas) in south east Queensland, Australia. PLoS ONE, San Francisco, v. 11, n. 2, p. 1-11, 2016.

CHEN, H. R. -J.; KUO, R. -J.; CHANG, T. -C.; HUS, C. -K.; BRAY, R. A.; CHENG, I. -J. Fluke (Spirorchiidae) infections in sea turtles stranded on Taiwan: prevalence and pathology. Journal of Parasitology, Lawrence, v. 98, n. 2, p. 437-439, 2012.

DiBENEDITTO, A. P. M.; AWABDI, D. R. How marine debris ingestion differs among megafauna species in a tropical area. Marine Pollution Bulletin, Oxford, v. 88, n. 1-2, p. 86-90, 2014.

DOMICIANO, I. G. Fibropapilomatose em tartarugasverde (Chelonia mydas, Linnaeus, 1758) no sudoeste do oceano Atlântico: epidemiologia e parâmetros clínicos laboratoriais. 2016. Tese (Doutorado em Ciência Animal) - Universidade Estadual de Londrina, Londrina.

DOMICIANO, I. G.; DOMIT, C.; ROSA, L.; MARCASSO, R. A.; BRACARENSE, A. P. F. R. L. Avaliação histopatológica de fibropapilomas em tartarugas marinhas no litoral do estado do Paraná. Archives of Veterinary Science, Curitiba, v. 18, n. 2, p. 401-403, 2013.

DONNELLY, K.; WALTZEK, T. B.; WELLEHAN JÚNIOR, J. F. X.; SUTTON, D. A.; WIEDERHOLD, N. P.; STACY, B. A. Phaeohyphomycosis resulting in an obstructive tracheitis in three green sea turtles Chelonia mydas stranded along the Florida coast. Diseases of Aquatic Organisms, Oldendorf, v. 113, n. 3, p. 257-262, 2015.

DUTRA, G. H. P.; NASCIMENTO, C. L.; FUTEMA, F. Fibromas viscerais associados ao fibropapiloma cutâneo em Chelonia mydas em reabilitação. Natural Resources, Coulterville, v. 2, n. 2, p. 50-62, 2012.

ENE, A.; SU, M.; LEMAIRE, S.; ROSE, C.; SCHAFF, S.; MORETTI, R.; LENZ, J.; HERBEST, L. H. Distribution of chelonid fibropapillomatosis-associated herpesvirus variants in Florida: molecular genetic evidence for infection of turtles following recruitment to neritic developmental habitats. Journal of Wildlife Diseases, Ames, v. 41, n. 3, p. 489-497, 2005.

FIEDLER, F. N.; SALES, G.; GIFFONI, B. B.; MONTEIRO-FILHO, E. L. A.; SECHI, E. R.; BUGONI, L. Drifnet fishery threats sea turtle in the Atlantic Ocean. Biodiversity Conservation, Madrid, v. 21, n. 4, p. 915931, 2012.
FLINT, M. Free-ranging sea turtle health. In: WYNEKEN, J.; LOHMANNK. J.; MUSICK, J. A. (Ed.). Biology of sea turtle. Boca Raton: CRC Press, 2013. v. 3, p. 379-398.

FLINT, M.; PETTERSON-KANE, J. C.; LIMPUS, C. J.; MILLS, P. C. Health surveillance of stranded green turtles in southern Queensland, Australia (2006-2009): an epidemiological analysis of causes of diseases and mortality. EcoHealth, New York, v. 7, n. 1, p. 135-145, 2010.

FLINT, M.; PETTERSON-KANE, J. C.; LIMPUS, C. J.; WORK, T. M.; BLAIR, D.; MILLS, P. C. Postmortem diagnostic investigation of disease in free-ranging marine turtle populations: a review of common pathologic findings and protocols. Journal of Veterinary Diagnostic Investigation, Columbia, v. 21, n. 6, p. 733-759, 2009.

FREITAS, J. F. T.; LENT, H. Porrocaecum sulcatum (Rudolphi, 1819) (Nematoda, Ascaroidea). Revista Brasileira de Biologia, Rio de Janeiro, v. 6, n. 2, p. 235238, 1946.

FUSSY, A.; POMMIER, P.; LUMBROSO, C.; HARO, L. Chelonitoxism: new case reports in French Polynesia and review of the literature. Toxicon, New York, v. 49, n. 6, p. 827-832, 2007.

GALLO, B. M. G.; MACEDO, S.; GIFFONI, B. B.; BECKER, J. H.; BARATA, P. C. R. Sea turtle conservation in Ubatuba, Southeastern Brazil, a feeding area with incidental capture in coastal fisheries. Chelonian Conservation and Biology, Lawrence, v. 5, n. 1, p. 93-101, 2006.

GAMA, L. R.; DOMIT, C.; BROADHURST, M. K.; FUENTES, M. M. P. B.; MILLAR, R. B. Green turtle (Chelonia mydas) foraging ecology at $25^{\circ}$ in the western Atlantic: evidence to support a feeding model driven by intrinsic and extrinsic variability. Marine Ecology Progress Series, Amelinghausen, v. 542, n. 1, p. 209-219, 2016.

GARCÍA-PÁRRAGA，D.; CRESPO-PICAZO，J. L.; QUIRÓZ, Y. B.; CERVERA, V.; MARTÍ-BONMATI, L.; DÍAZ-DELGADO, J.; ARBELO, M.; MOORE, M. J.; JEPSON, P. D.; FERNÁNDEZ, A. Decompression sickness (the bends) in sea turtles. Diseases of Aquatic Organisms, Oldendorf, v. 111, n. 3, p. 191-205, 2014.

GAUS, C.; GRANT, S.; JIN, N. L.; GOOT, K.; CHEN, L.; VILLA, A.; NEUGEBAUER, F.; QI, L.; LIMPUS, C. Investigation of contaminant levels in Green turtles from Gladstone: final report. Brisbane: National Research Centre for Environmental Toxicology (Entox), 2012. 160 p. 
GEORGE, R. H. Health problems and diseases of sea turtles. In: LUTZ, L.; MUSICK, J. A. (Ed.). The biology of sea turtles. Boca Raton: CRC Press, 1997. v. 1, p. 363386.

GLAZEBROOK, J. S.; CAMPBELL, R. S. F. A survey of the diseases of marine turtles in northern Australia. I. Farmed turtles. Diseases of Aquatic Organisms, Oldendorf, v. 9, n. 1, p. 83-95, 1990a.

A survey of the diseases of marine turtles in northern Australia. II. Oceanarium- reared and wild turtles. Diseases of Aquatic Organisms, Oldendorf, v. 9, n. 1, p. 97-104, 1990b.

GOLDBERG, D. W.; ALMEIDA, D. T.; TOGNIN, F.; LOPEZ, G. G.; PIZETTA, G. T. -D.; LEITE JÚNIOR, N. O.; SFORZA, R. Hopper dredging impacts on sea turtles on the northern coast of Rio de Janeiro State, Brazil. Marine Turtle Newsletter, La Jollo, v. 147, n. 1, p. 16-20, 2015.

GOLDBERG, D. W.; STAHELIN, G. D.; CEGONI, C. T.; WANDERLINDE, J.; LIMA, E. P.; MEDINA, R. M.; RIBEIRO, R. B.; SILVA, M. A.; CARVALHO, E. C. Q. Case report: lung spirorchidiasis in a Green turtle (Chelonia mydas) in southern Brazil. Marine Turtle Newsletter, La Jollo, v. 139, n. 1, p. 1-14, 2013.

GONZÁLEZ-CARMAN, V.; ACHA, E. M.; MAXWELL, S. M.; ALBAREDA, D.; CAMPAGNA, C.; MIANZAN, H. Young green turtles, Chelonia mydas, exposed to plastic in a frontal area of the SW Atantic. Marine Pollution Bulletin, Oxford, v. 78, n. 1-2, p. 5662, 2014.

GORDON, A. N.; KELLY, W. R.; CRIBB, T. H. Lesions caused by cardiovascular flukes (Digenea: Spirorchidae) in stranded green turtles (Chelonia mydas). Veterinary Pathology, Washington, v. 35, n. 1, p. 21-30, 1998.

GORDON, A. N.; KELLY, W. R.; LESTER, R. J. G. Epizootic mortality of free-living green turtles, Chelonia mydas, due to coccidiosis. Journal of Wildlife Diseases, Ames, v. 29, n. 3, p. 490-494, 1993.

GREENBLATT, R. J.; WORK, T. M.; DUTTON, P.; SUTTON, C. A.; SPRAKER, T. R.; CASEY, R. N.; DIEZ, C. E.; PARKER, D.; St LEGER, J.; BALAZS, G. H.; CASEY, J. W. Geographic variation in marine turtle fibropapillomatosis. Journal of Zoo and Wildlife Medicine, Lawrence, v. 36, n. 3, p. 527-530, 2005.

GUEBERT-BARTHOLO, F. M.; BARLETTA, M.; COSTA, M. F.; MONTEIRO-FILHO, E. L. A. Using gut contents to assess foraging patterns of juvenile green turtles Chelonia mydas in the Paranaguá estuary, Brazil. Endangered Species Research, Oldendorf, v. 13, n. 2, p. 131-143, 2011.
HADDAD JÚNIOR, V. Ingestion of aquatic venomous animals: toxinology, clinical aspects, and treatment. In: . Medical emergencies caused by aquatic animals: a zoological and clinical guide. Switzerland: Springer Publishers, 2016. p. 87-102.

HARVELL, C. D.; KIM, K.; BURKHOLDER, J. M.; COLWELL, R. R.; EPSTEIN, P. R.; GRIMES, D. J.; HOFMANN, E. E.; LIPP, E. K.; OSTERHAUS, A. D. M. E.; OVERSTREET, R. M.; PORTER, J. W.; SMITH, G. W.; VASTA, G. R. Emerging marine diseases-climate links and anthropogenic factors. Science's Compass, Washington, v. 285, n. 5433, p. 1505-1510, 1999.

HERBST, L. H. Fibropapillomatosis of marine turtles. Annual Review of Fish Diseases, Danvers, v. 4, n. 6, p. 389-425, 1994.

INSTITUTO CHICO MENDES DE CONSERVAÇÃO DA BIODIVERSIDADE - ICMBio. Portaria $\mathrm{N}^{\circ} 444$, de 17 de dezembro de 2014. Lista Nacional Oficial de Espécies Ameaçadas de Extinção. Brasília: ICP, 2014. Disponível em: <http://www.icmbio.gov.br/ portal/images/stories/biodiversidade/fauna-brasileira/ avaliacao-do-risco/PORTARIA_N\%C2\%BA_444 DE_17_DE_DEZEMBRO_DE_2014.pdf $>$. Acesso em: 20 jan. $201 \overline{7}$.

INTERNATIONAL UNION FOR CONSERVATION OF NATURE - IUCN. Searching for conservation status of sea turtles data. Cambridge: IUCN, 2017. Available at: <http://www.iucnredlist.org/search>. Accessed at: 20 jan. 2017.

ISLAM, S.; TANAKA, M. Impacts of pollution on coastal and marine ecosystems including coastal and marine fisheries and approach for management: a review and synthesis. Marine Pollution Bulletin, Oxford, v. 48, n. 7-8, p. 624-649, 2004.

JACOBSON, E. R.; GASKIN, J. M.; ROELKE, M.; GREIMER, E. C.; ALLEN, J. Conjunctivitis, tracheitis, and pneumonia associated with herpesvirus infection in green sea turtles. Journal of American Veterinary Medical Association, New York, v. 189, n. 9, p. 1020-1023, 1986.

JOHNSON, J. C.; SCHWIESON, T.; EKWALL, A. K.; CHRISTIANSEN, J. L. Reptilian melanomacrophages function under conditions of hypothermia: observations on phagocytic behavior. Pigment Cell Research, Oxford, v. 12, n. 6, p. 376-382, 1999.

JONES, K.; ARIEL, E.; BURGESS, G.; READ, M. A review of fibropapillomatosis in green turtles (Chelonia mydas). The Veterinary Journal, London, v. 212, n. 1, p. 48-57, 2016.

KELLER, J. M. Exposure to and effects of persistent organic pollutants. In: WYNEKEN, J.; LOHMANN, K. 
J.; MUSICK, J. A. (Ed.). The biology of sea turtles. Boca Raton: CRC Press, 2013. v. 3, p. 285-328.

KOMOROSKE, L. M.; LEWISON, R. L.; SEMINOFF, J. A.; DEHEYN, D. D.; DUTTON, P. H. Pollutants and the health of green sea turtles resident to an urbanized estuary in San Diego, CA. Chemosphere, Oxford, v. 84, n. 5, p. 544-552, 2011.

LABRADA-MARTAGÓN, V.; RODRÍGUEZ, P. A. T.; MÉNDEZ-RODRÍGUEZ, L. C.; ZENTENO-SAVÍN, T. Oxidative stress indicators and chemical contaminants in East Pacific green turtles (Chelonia mydas) inhabiting two foraging coastal lagoons in the Baja California peninsula. Comparative Biochemistry and Physiology, Part C, New York, v. 154, n. 2, p. 65-75, 2011.

LAUCKNER, G. Diseases of reptilia. In: KINNE, O. (Ed.). Diseases of marine animals: introduction, Reptilia, Aves, Mammalia. v. IV, Part 2. Helgoland: Biologische Anstalt Helgoland, 1985. p. 553-626.

LEWISON, R.; WALLACE, B.; ALFARO-SHIGUETO, J.; MANGEL, J. C.; MAXWELL, S. M.; HAZEN, E. L. Fisheries bycatch of marine turtles: lessons lerned from decades of research and conservation. In: WYNEKEN, J.; LOHMANN, K. J.; MUSICK, J. A. (Ed.). The biology of sea turtles. Boca Raton: CRC Press, 2013. v. 3, p. 329351.

LICHTENFELS, J. R.; BIER, J. W.; MADDEN, P. A. Larval anisakid (Sulcascaris) nematodes from Atlantic molluscs with marine turtles as definitive hosts. Transactions of the American Microscopical Society, Lawrence, v. 97, n. 2, p. 199-207, 1978.

LIMA, E. H. S. M.; LAGUEUX, C. J.; CASTRO, W.; MARCOVALDI, M. A. From one feeding ground to another: green turtle migration from Brazil to Nicaragua. Marine Turtle Newsletter, La Jollo, v. 85, n. 1, p. 1-10, 1999.

LIMA, E. H. S. M.; TROËNG, S. Link between green turtles foraging in Brazil and nesting in Costa Rica?. Marine Turtle Newsletter, La Jollo, v. 94, n. 1, p. 1-9, 2001.

LÓPEZ-BARRERA, E. A.; LONGO, G. O.; MONTEIRO-FILHO, E. L. A. Incidental capture of green turtle (Chelonia mydas) in gillnets of small-scale fisheries in Paranaguá Bay, southern Brazil. Ocean \& Costal Management, Amsterdam, v. 60, n. 1, p. 11-18, 2012.

LUSCHI, P.; HAYS, G. C.; DelSAPPIA, C.; MARSH, R.; PAPI, F. The navigational feats of green sea turtles migration from Ascension Island investigated by satellite telemetry. Proceedings of the Royal Society of London. Series B, London, v. 265, n. 1412, p. 2279-2284, 1998.
LUTZ, P. L. Studies on ingestion of plastic and latex by sea turtles. In: INTERNATIONAL CONFERENCE ON MARINE DEBRIS, 1990, Honolulu. Proceedings... Honolulu: US Department of Commerce NOM Tech Memo, 1990. p. 2-7.

MACÊDO, G. R.; TARANTINO, T. B.; BARBOSA, I. S.; PIRES, T. T.; ROSTAN, G.; GOLDBERG, D. W.; PINTO, L. F. B.; KORN, M. G. A.; FRANKE, C. R. Trace elements distribution in hawksbill turtle (Eretmochelys imbricata) and green turtles (Chelonia mydas) tissues on the northern coast of Bahia, Brazil. Marine Pollution Bulletin, Oxford, v. 94, n. 1-2, p. 284-289, 2015.

MANIRE, C. A.; STACY, B. A.; KINSEL, M. J.; DANIEL, H. T.; ANDERSON, E. T.; WELLEHAN JUNIOR, J. F. X. Proliferative dermatitis in a loggerhead turtle, Caretta caretta, and a green turtle, Chelonia mydas, associated with novel papillomavirus. Veterinary Microbiology, Amsterdam, v. 130, n. 3-4, p. 227-237, 2008.

MENDES, S. S.; CARVALHO, R. H.; FARIA, A. F.; SOUSA, B. M. Marine debris ingestion by Chelonia mydas (Testudines: Cheloniidae) on the Brazilian coast. Marine Pollution Bulletin, Oxford, v. 92, n. 1-2, p. 8-10, 2015.

MONEZI, T. A.; MEHNERT, D. U.; MOURA, M. M.; MULLER, N. M. G.; GARRAFA, P.; MATUSHIMA, E. R.; WERNECK, M. R.; BORELLA, M. I. Chelonid herpesvirus 5 in secretions and tumor tissues from green turtles (Chelonia mydas) from southeastern Brazil: a tenyear study. Veterinary Microbiology, Amsterdam, v. 186, n. 1, p. 150-156, 2016.

MONTEIRO, D.; ESTIMA, S. C.; GANDRA, T. B. R.; SILVA, A. P.; BUGONI, L.; SWIMMER, Y.; SEMINOFF, J. A.; SECCHI, E. Long-term spatial and temporal patterns of sea turtle strandings in southern Brazil. Marine Biology, Berlin, v. 163, n. 12, p. 1-19, 2016.

NARO-MACIEL, E.; BONDIOLI, A. C. V.; MARTIN, M.; ALMEIDA, A. P.; BAPTISTOTTE, C.; BELLINI, C.; MARCOVALDI, M. Â.; SANTOS, A. J. B.; AMATO, $\mathrm{G}$. The interplay of homing and dispersal of green turtles: a focus on the southwestern Atlantic. Journal of Heredity, Cary, v. 103, n. 6, p. 792-805, 2012.

NARO-MACIEL, E.; REID, B. N.; ALTER, S. E.; AMATO, G.; BJORNDAL, K. A.; BOLTEN, A. B.; MARTIN, M.; NAIRN, C. J.; SHAMBLIN, B.; PINEDA-CATALAN, O. From refugia to rookeries: phylogeography of Atlantic green turtles. Journal of Experimental Marine Biology and Ecology, Amsterdam, v. 461, n. 1, p. 306-316, 2014. 
NELMS, S. E.; DUNCAN, E. M.; BRODERICK, A. C.; GALLOWAY, T. S.; GODFREY, M. H.; HAMANN, M.; LINDEQUE, P. K.; GODLEY, B. J. Plastic and marine turtles: a review and call for research. ICES Journal of Marine Science, Oxford, v. 73, n. 2, p. 165-181, 2016.

ORÓS, J.; CALABUIG, P.; DÉNIZ, S. Digestive pathology of sea turtles stranded in the Canary islands between 1993 and 2001. Veterinary Record, London, v. 155, n. 6, p. 169-174, 2004.

ORÓS, J.; TORRENT, A.; CALABUIG, P.; DÉNIZ, S. Diseases and causes of mortality among sea turtles stranded in the Canary Islands, Spain (1998-2001). Diseases of Aquatic Organisms, Oldendorf, v. 63, n. 1, p. 13-24, 2005.

PHILLIPIS, B. E.; CANNIZZO, S. A.; GODFREY, M. H.; STACY, B. A.; HARMA, C. A. Exertional myopathy in a juvenile green sea turtle (Chelonia mydas) entangled in large mesh gillnet. Cases Reports in Veterinary Medicine, New York, v. 2015, n. 1, p. 1-6, 2015.

PRITCHARD, P. C. H. Post-nesting movements of marine turtles (Cheloniidae and Dermochelyidae) tagged in the Guianas. Copeia, Lawrence, v. 1, n. 4, p. 749-754, 1976.

PUPO, M. M.; SOTO, J. M. R.; HANAZAKI, N. Captura incidental de tartarugas marinhas na pesca artesanal da Ilha de Santa Catarina, SC. Biotemas, Florianópolis, v. 19, n. 4, p. 63-72, 2006.

RAIDAL, S. R.; OHARA, M.; HOBBS, R. P.; PRINCE, R. Gram-negative bacterial infections and cardiovascular parasitism in green sea turtles (Chelonia mydas). Australian Veterinary Journal, Brunswick, v. 76, n. 6, p. 415-417, 1998.

REIF, J. S. Animal sentinels for environmental and public health. Public Health Reports, Rockville, v. 126, p. 5057, 2011. Supplement 1.

RODENBUSCH, C. R.; BAPTISTOTTE, C.; WERNECK, M. R.; PIRES, T. T.; MELO, M. T. D.; ATAIIDE, M. W.; REIS, K. D. H. L.; TESTA, P.; ALIEVE, M. M.; CANAL, C. W. Fibropapillomatosis in green turtles Chelonia mydas in Brazil: characteristics of tumors and virus. Disease of Aquatic Organisms, Oldendorf, v. 111, n. 3, p. 207-217, 2014.

SALES, G.; GIFFONI, B. B.; BARATA, P. C. R. Incidental catch of sea turtles by the Brazilian pelagic longline fishery. Journal of Marine Biological Association of the United Kingdom, Kristineberg, v. 88, n. 4, p. 853-864, 2008.

SANCHEZ-SARMIENTO, A. M.; ROSSI, S.; VILCA, F. Z.; VANSTREELS, R. E. T.; MONTEIRO, S. H.; VALE,
L. A. S.; SANTOS, R. G.; MARIGO, J.; BERTOZZI, C. P.; GRISI-FILHO, J. H. H.; TORNISIELO, V. L.; MATUSHIMA, E. R. Organochlorine pesticides in green turtles (Chelonia mydas) with and without fibropapillomatosis caught at three feeding areas off Brazil. Journal of Marine Biological Association of the United Kingdom, Kristineberg, v. 97, n. 1, p. 215-223, 2017.

SANTORO, M.; MORALES, J. A.; RODRÍGUEZORTÍZ, B. Spirorchiidiosis (Digenea: Spirorchiidae) and lesions associated with parasites in Caribbean green turtles (Chelonia mydas). The Veterinary Record, London, v. 161, n. 14, p. 482-486, 2007.

SANTOS, A. S.; ALMEIDA, A. P.; SANTOS, A. J. B.; GALlO, B.; GIFFONI, B.; BAPTISTOTTE, C.; COELHO, E.; LIMA, E. H. S. M.; SALES, G.; LOPEZ, G. G.; STAHELIN, G.; BECKER, H.; CASTILHOS, J. C.; THOMÉ, J. C. A.; WANDERLINDE, J.; MARCOVALDI, M. A. A. G.; MENDILAHARSU, M. M. L.; DAMASCENO, M. T.; BARATA, P. C. R.; SFORZA, R. Plano de ação nacional para conservação das tartarugas marinhas. Brasília: Instituto Chico Mendes de Conservação da Biodiversidade, ICBio, 2011. $120 \mathrm{p}$.

SANTOS, R. G.; ANDRADES, R.; BOLDRINI, M. A.; MARTINS, A. S. Debris ingestion by juvenile marine turtles: an understimated problem. Marine Pollution Bulletin, Oxford, v. 93, n. 1-2, p. 37-43, 2015.

SANTOS, R. G.; MARTINS, A. S.; TOREZANI, E.; BAPTISTOTTE, C.; FARIAS, J. N.; HORTA, P. A.; WORK, T. M.; BALAZS, G. H. Relationship between fibropapillomatosis and environmental quality: a case study with Chelonia mydas off Brazil. Diseases of Aquatic Organisms, Oldendorf, v. 89, n. 1, p. 87-95, 2010.

SCHUYLER, Q. A.; HARDESTY, B. D.; WILCOX, C.; TOWNSEND, K. Global analysis of anthropogenic debris ingestion by sea turtles. Conservation Biology, Boston, v. 28, n. 1, p. 129-139, 2014a.

SCHUYLER, Q. A.; WILCOX, C.; TOWNSEND, K.; HARDESTY, B. D.; MARSHALL, N. J. Mistaken identity? Visual similarities of marine debris to natural prey items of sea turtles. BioMed Central Ecology, London, v. 14, n. 14, p. 2-7, 2014 b.

SILVA, C. C.; KLEIN, R. D.; BARCAROLLI, I. F.; BIANCHINI, A. Metal contamination as a possible etiology of fibropapillomatosis in juvenile female green turtles Chelonia mydas from the southern Atlantic Ocean. Aquatic Toxicology, Amsterdam, v. 170, n. 1, p. 42-51, 2016. 
SMITH, G. M.; COATES, C. W.; NIGRELLI, R. F. A. A papillomatous disease of the gallbladder associated with infection of flukes, occurring in the marine turtle, Chelonia mydas (Linnaeus). Zoologia, New York, v. 26, n. 5, p. 13-16, 1941.

STACY, B. A.; FOLEY, A. M.; GREINER, E.; HERBST, L. H.; BOLTEN, A.; KLEIN, P.; MANIRE, C. A.; JACOBSON, E. R. Spirorchiidiasis in stranded loggerhead Caretta caretta and green turtles Chelonia mydas in Florida: host pathology and significance. Diseases of Aquatic Organisms, Oldendorf, v. 89, n. 3, p. 237-259, 2010.

STACY, B. A.; SANTORO, M.; MORALES, J. A.; HUZELLA, L. M.; KALASINSKY, V. F.; FOLEY, A.; METTEE, N.; JACOBSON, E. R. Renal oxalosis in free-ranging green turtles Chelonia mydas. Diseases of Aquatic Organisms, Oldendorf, v. 80, n. 1, p. 45-49, 2008.

TERYDA, N. S. Evaluación de la ingestion de residuos antrópicos de la tortuga verde (Chelonia mydas) en Uruguay. 2015. Tesis (Licenciatura en Ciencias Biológicas) - Universidad Nacional de Mar del Plata, Buenos Aires.

TORRES, R. J.; ABESSA, D. M. S.; SANTOS, F. C.; MARANHO, L. A.; DAVANSO, M. B.; NASCIMENTO, M. R. L.; MOZETO, A. A. Effects of dredging operations on sediment quality: contaminant mobilization in dredged sediments from the Port of Santos, SP, Brazil. Journal of Soils and Sediments, Denmark, v. 9, n. 5, p. 420-432, 2009.

TOURINHO, P.; SUL, J. A. I. do; FILLMANN, G. Is marine debris ingestion still a problem for the coastal marine biota of southern Brazil? Marine Pollution Bulletin, Oxford, v. 60, n. 3, p. 396-401, 2010.

WALLACE, B. P.; DiMATTEO, A. D.; BOLTEN, A. B.; CHALOUPKA, M. Y.; HUTCHINSON, B. J.; ABREUGROBOIS, F. A.; MORTIMER, J. A.; SEMINOFF, J. A.; AMOROCHO, D.; BJORNDAL, K. A.; BOURJEA, J.; BOWEN, B. W.; DUEÑAS, R. B.; CASALE, P.; CHOUDHURY, B. C.; COSTA, A.; DUTTON, P. H.; FALLABRINO, F.; FINKBEINER, E. M.; GIRARD, A.; GIRONDOT, M.; HAMANN, M.; HURLEY, B. J.; LÓPEZ-MENDILAHARSU, M.; MARCOVALDI, M. A.; MUSICK, J. A.; NEL, R.; PILCHER, N. J.; TROËNG, S.; WITHERINGTON, B.; MAST, R. B. Global conservation priorities for marine turtles. PloS ONE, San Francisco, v. 6, n. 9, p. 1-14, 2011.

WALLACE, B. P.; KOT, C. Y.; DiMATTEO, A. D.; LEE, T.; CROWDER, L. B.; LEWISON, R. L. Impacts of fisheries bycatch on marine turtle populations worldwide: toward conservation and research priorities. Ecosphere, Washington, v. 4, n. 3, p. 1-49, 2013.

WARWICK, C.; ARENA, P. C.; STEEDMAN, C. Health implications associated with exposure to farmed and wild sea turtles. Journal of Royal Society of Medicine Short Reports, London, v. 4, n. 8, p. 1-7, 2013.

WERNECK, M. R.; BINOTI, E.; MARTINS, I. V. F.; CALAIS JUNIOR, A.; GOMES, M. C.; BOELONI, J. N.; TRAZZI, A.; BERGER, B. Occurrence of Rhytidodoides similis Price, 1939 (Digenea, Rhytidodidae) and lesions due to Spirorchiid eggs in a green turtle, Chelonia mydas Linnaeus, 1758 (Testudines, Cheloniidae), from Brazil. Comparative Parasitology, Lawrence, v. 82, n. 2, p. 291295, 2015 b.

WERNECK, M. R.; SOUZA, G. B.; BERGER, B. C.; TRAZZI, A.; RIBEIRO, R. B.; SILVA, M. A.; LEANDRO, H. J.; CARVALHO, E. C. Q. Pathological changes by Hapalotrema postorchis Rao 1976 (Digenea: Spirorchiidae) in a green turtle Chelonia mydas Linnaeus 1758 (Testudines, Cheloniidae) from Brazil. Helminthologia, Bratislava, v. 52, n. 2, p. 148-154, $2015 \mathrm{a}$.

WOBESER, G. A. Diseases in wild animals: investigation and management. Heidelberg: Verlag Berlin HeidelbergSpringer, 2007. 393 p.

WOLKE, R. E.; BOOKS, D. R.; GEORGE, A. Spirorchidiasis in loggerhead sea turtles (Caretta caretta): pathology. Journal of Wildlife Diseases, Ames, v. 18 , n. 2, p. 175-185, 1982.

WORK, T. M.; BALAZS, G. H. Pathology and distribution of sea turtles landed as bycatch in the Hawaiibased North Pacific pelagic longline fishery. Journal of Wildlife Diseases, Ames, v. 46, n. 2, p. 422-432, 2010.

WORK, T. M.; BALAZS, G. H.; RAMEYER, R. A.; MORRIS, R. A. Retrospective pathology survey of green turtles Chelonia mydas with fibropapillomatosis in the Hawaiian islands, 1993-2003. Diseases of Aquatic Organisms, Oldendorf, v. 62, n. 1-2, p. 163-176, 2004.

WORK, T. M.; BALAZS, G. H.; SCHUMACHER, J. L.; MARIE, A. Epizootiology of Spirorchiid infection in green turtles (Chelonia mydas) in Hawaii. Journal of Parasitology, Lawrence, v. 91, n. 4, p. 871-876, 2005.

WORK, T. M.; BALAZS, G. H.; SUMMERS, T. M.; HAPDEI, J. R.; TAGARINO, A. P. Causes of mortality in green turtles from Hawaii and the insular Pacific exclusive of fibropapillomatosis. Diseases of Aquatic Organisms, Oldendorf, v. 115, n. 2, p. 103-110, 2015a.

WORK, T. M.; BALAZS, G. H.; WOLCOTT, M.; MORRIS, R. Bacteraemia in free-ranging Hawaiian 
green turtles Chelonia mydas with fibropapillomatosis. Diseases of Aquatic Organisms, Oldendorf, v. 53, n. 1, p. 41-43, 2003.

WORK, T. M.; DAGENAIS, J.; BALAZS, G. H.; SCHETTLE, N.; ACKERMANN, M. Dynamics of virus shedding and in situ confirmation of Chelonid Herpesvirus 5 in Hawaiian green turtles with fibropapillomatosis. Veterinary Pathology, Washington, v. 52, n. 6, p. $1195-$ 1201, $2015 b$.
XAVIER, R. A. Análise da fauna parasitológica gastrointestinal de Chelonia mydas (Linnaeus, 1758) no litoral norte e médio do Rio Grande do Sul, Brasil. 2011. Monografia (Trabalho de Conclusão de Curso de Graduação em Ciências Biológicas) - Universidade Federal do Rio Grande do Sul, Imbé. 